\title{
小流域水土保持综合治理策略探讨
}

\author{
高亚莉
}

延安市宝塔区水土保持工作队

DOI:10.32629/hwr.v3i2.1903

[摘 要] 近年来,社会经济的发展, 随之而来的是严重的生态环境问题,直接影响到了我国社会经济的可持续发展。基于我国现 阶段提出的可持续发展,响应节能减排等具体要求, 需要注重生态环境问题的治理。在整个社会建设过程中, 小流域水土出现了 严重的问题。因此, 相关人员或者是相关部门需要对此引起高度重视,并加以有效措施治理,才能为我国社会主义建设发展夯实 基础。本文主要以小流域水土保持为中心论述点, 从小流域治理规划、治理方法、循环机制以及流域产品流通等四个方面入 手,提出了小流域水土保持综合治理策略,旨在小流域水土保持综合治理水平。

[关键词] 小流域水土保持; 综合治理; 策略

社会的发展, 虽促进了广大群众生活质量的提升, 但是 在一些不靠近人们生活的地区, 出现了较为严重的生态环境 问题, 直接影响到了社会的可持续发展。近些年来, 社会的快 速发展, 无其是城镇化进程的加快, 人们身边的生态环境也 出现了一定的问题。基于这一背景, 人们生态环境保护意识 不断增多, 并积极采取有效措施用于环境保护。小流域水土 流失作为生态环境恶化的一种具体表现, 其是否及时得到合 理的治理, 直接关系到水土资源社会效益、生态效益以及经 济效益的发展。基于此, 小流域水土保持综合治理显得尤为 重要, 并且此项工作迫在眉睫。鉴于此, 本文对 “小流域水土 保持综合治理策略” 展开更深层次的剖析具备极为重要的现 实意义有价值。

\section{1 规划小流域水土保持综合治理}

小流域水土保持综合治理过程中, 需要制定综合治理规 划, 明确规划方向, 由此保证综合治理与开发利用协调发展。 就目前小流域水土保持综合治理情况而言, 所采取的方式主 要是结以小流域为单元, 结合自然条件、社会经济等, 合理安 排农业、牧业等用地情况。在此基础上, 选择合适的综合治 理方案, 结合区域经济发展规划, 开展小流域水土保持综合 治理工作, 由此保证小流域生态经济效益的提高。首先, 基于 区域总体规划开展小流域水土保持综合治理工作。结合总体 规划, 制定详细的治理工作方案, 促使小流域经济与区域经 济发展脚步保持一致。其次, 立足于区域总体规划明确综合 治理具体要求。小流域水土综合治理具体要求涉及到三个方 面: 一是遵循总体布局, 在满足区域规划的具体要求下, 开展 小流域水土综合治理工作, 在有效避免水土流失问题再次发 生的情况下, 不断开发小流域水土, 促进经济效益的增长; 二 是采取种植植物措施, 结合小流域的具体特点, 选择合适的 物种建林; 三是结合小流域的自然特征, 采取合理的防护措 施, 避免遭受自然灾害的破坏。最后, 立足于总体规划角度制 定种植方案 ${ }^{[1]}$ 。基于可持续发展理念, 在防护措施中, 应该以 植物措施为主, 工程措施为辅 ${ }^{[2]}$ 。另外, 相关人员需要结合市 场需求, 选择合适的种植方案, 减少市场风险的同时, 有效促
进小流域经济效益的增长。

\section{2 构建大样板生产基地}

就目前小流域水土保持综合治理而言, 在具体的规划中, 主要以小流域为单元, 各个小流域之间较为分散, 形成了一 个小规模治理现状。各个小流域之间缺乏相应的产业支撑, 外加采取的管理方式主要以粗旷性为主, 直接造成技术作用 无法发挥出来, 进而影响到了小流域经济效益的增长 ${ }^{[3]}$ 。针 对这一问题, 需要将小流域分散治理转变为规范化治理。具 体言之, 就是将各个小流域集合起来, 形成一片, 构建大样板 生产基地。这种方式, 不仅有利于农业技术指导, 还能够有效 减少管理人员成本输出。除此之外, 土地分散经营格局的打 破, 构建了一个大营户为主的经营模式, 能够实现产、供、销一 体化的经营格局, 这对小流域水土保持综合治理质量的提升有 着积极作用, 同时能够有效促进小流域生产效益的增长 ${ }^{[4]}$ 。基 于市场经济角度而言, 小流域由分散经营转变为集中经营, 即 实现了规模化经营, 最大的变化在于由小流域自然经济转变 为了市场经济 ${ }^{[5]}$ 。然而在市场经济体制下, 小流域的经济效 益将会持续增长, 逐渐成为小流域治理后的支柱产业。同时 以市场经济发展为导向, 小流域经济发展为核心, 以治理水 土流失为手段, 构建了小流域规模化与规范化治理体系。这 样一来, 小流域水体保持综合治理效果将会大大提升, 同时 小流域治理后有了产业支撑, 可以实现小流域水土保持综合 治理后长期的经济效益。

\section{3 构建循环机制,形成产业关联系统}

小流域水土保持综合治理过程中, 需在严格遵循区域总 体规划具体要求下, 逐一对小流域进行综合治理, 其最终目 的在于治理小流域水土流失问题, 着重小流域经济发展。具 体言之, 在小流域水土保持综合治理中, 需要将小流域逐个 治理好, 并结合小流域的具体情况, 例如自然条件、地理条件 等, 选择行之有效的综合治理模式, 布设植物种植方案, 结合 小流域内农业、渔业等产业能量循环机制, 构建一个小流域 内部循环机制, 形成产业关联系统[6]。总之, 小流域水土保持 综合治理之后, 需达到降低治理成本与劳动力输出目标的基 
础上, 有效改善小流域生态环境, 切实提高小流域总体生态 效益与经济效益。首先, 小流域中应该结合具体情况, 注重种 植面积的开拓, 同时需要以牧业为基础, 大力发展饲料加工 产业, 同时注重畜禽饲养业的发展, 基于环境保护角度, 将畜 禽粪便用于发酵田地, 以此促进种植业的发展, 真正意义上 利用现有资源, 降低成本, 提高收益, 同时保护了生态环境。 其次, 建立小流域支柱产业, 通常选择畜牧业为主, 借助小流 域独有的自然条件与交通地理位置优势, 加强林果业的发展, 不断开拓经济收入项目, 形成农业、林业、牧业以及果业为 一体的生态循环机制, 最终实现小流域水土保持综合治理目 标, 同时可以促进小流域社会效益、经济效益与生态经济的 同步增长。

\section{4 制动综合管控构架,全方位综合管理}

小流域水土保持综合治理不仅仅是一个小流域的治理, 而是需要将所有的小流域问题彻底解决, 加强全方位管理, 并促进小流域经济的发展。因此, 有必要加强认识, 这就需要 在加强全方位管理中, 加大对小流域水土保持综合治理的宣 传工作, 促使社会对小流域水土保持综合治理具有一个更深 的认识, 并由此引起社会各界的重视, 才能有效凝聚社会的 全部力量, 为小流域水土保持综合治理工作的开展提供一系 列有效帮助。与此同时, 各区域自身需要认识到小流域水土 保持综合治理的重要性, 并在具体工作中, 加强落实相关制 度, 优化资源配置, 才能达到最佳小流域水土保持综合治理 效果。首先, 加大宣传力度。加强当地媒体合作, 充分发挥现 代媒体的作用, 全面宣传环保工作, 提高社会广大群众的环 境意识, 促使其在日常工作中, 积极参与到小流域水土保持 综合治理中。其次, 加强领导, 充分发挥各个区域机关部门的 作用, 合理规划各部门的治理权责, 由此有序开展小流域水 土保持综合治理工作。同时需要制定相关的规章制度, 保证 各项工作的落实。针对小流域水土保持综合治理工作未落实 部门, 需要追究相关负责人的责任, 基于此需要建立相应的 责任追究制, 保证各项工作能够按照规划落实, 才能真正意
义上保障小流域水土保持综合治理效果。三是加大创新力 度。立足于可持续发展, 结合小流域经济发展情况, 创新综合 治理方式, 基于大局角度, 开展小流域水土保持综合治理工 作。与此同时, 深刻认识到小流域水土保持综合治理的最终 目标, 需要以小流域经济发展, 降低能源消耗为最终目标, 选 择合适的治理模式, 最终提高小流域水土保持综合治理水 平。最后, 制定奖惩制度。奖惩制度的制定与实施, 目的在于 规范小流域水土保持综合治理工作中一些工作人员的具体 行为, 促使相关管理人员在具体的工作中, 有所作为。积极引 导广大群众参与小流域水土保持综合治理监督, 形成内外协 同监督机制, 完善举报投诉体系, 由此切实提高小流域水土 保持综合治理效率。

\section{5 结语}

综上所述, 小流域水土保持综合治理工作作为一项综合 性工作, 涉及到经济等多个方面的内容。因此, 有必要立足于 小流域经济可持续发展, 通过规划小流域水土保持综合治 理、构建大样板生产基地、构建循环机制, 形成产业关联系 统以及制动综合管控构架, 全方位综合管理等举措, 切实提 升小流域水土保持综合治理效率与水平。

\section{[参考文献]}

[1]王慧琴.面向生态保护的丘陵地区小流域水土保持 [J].农家参谋,2019,(05):205.

[2]赵国秀.小流域水土保持规划的布局研究[J].地下 水,2019,41(01):200-202.

[3]洪宇.朝阳县七道岭小流域水土保持生态服务价值评 价[J].地下水,2019,41(01):203-204.

[4]马克宁.西南地区小流域水土保持综合治理实施研究 [J].中国新技术新产品,2019,(01):134-135.

[5]齐实,刘斗,毕超,等.北京市小流域水土保持安全研究 [J].中国水土保持科学,2018,16(06):79-88.

[6]李孝娟.低山丘陵区小流域水土保持治理措施及效益 分析[J].吉林农业,2018,(24):63. 